\title{
The FOMC in 1989: Walking a Tightrope
}

3. HE FEDERAL Open Market Committee (FOMC) sought to balance the risk of inflationary pressures against that of a weakening economy in 1989, the seventh year of the current economic expansion. ${ }^{1}$ The changing relative intensity of these risks, as perceived by the FOMC (hereafter, the Committee), influenced the course of monetary policy throughout the year.

Because the Committee believed that long-run price stability is necessary to promote maximum sustainable economic growth over time, the perceived risks of inflationary pressures greatly influenced its decisions early in the year. As the year progressed, however, it became increasingly apparent to the Committee that the economic expansion was weakening. At the same time, the Committee's perception of the trend in inflation became slightly more optimistic. Accordingly, the weight that the Committee attached to reducing the risks of a slowdown in economic activity increased somewhat throughout the second half of 1989. Nevertheless, the Committee's concern about future price pressures and the importance of maintaining its own credibility as an inflation-fighter remained in the forefront of its deliberations.

This article reviews the formulation of monetary policy by the Committee in 1989. The discussion focuses on how changing economic conditions influenced the Committee's decisions as it balanced the risk of future inflation against that of a future slowdown in economic activity.

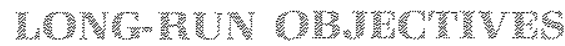

The Board of Governors of the Federal Reserve System reports to Congress twice a year on its annual growth rate targets for the monetary and debt aggregates. The one-year target periods run from the fourth quarter of the previous year to the fourth quarter of the current year. These reports are mandated by the Full Employment and Balanced Growth Act of 1978 (or the Humphrey-Hawkins Act). After its first meeting of the year in February, the Committee submits a report on its monetary and debt growth objectives for the current year. In July, upon reviewing the progress it has made toward achieving its objectives for the
NOTE: Citations to the Record refer to the "Record of Policy Actions of the Federal Open Market Committee" as published in vartous issues of the Federal Reserve Bulletin. Citations to "Report" refer to the "Monetary Policy Report to the Congress," which is also published in the Federal Reserve Bulletin.
tSee the shaded insert on pages 18 and 19 for a description of the Committee's membership during 1989. 


\section{Organization Of The Committee}

The Federal Open Market Committee (FOMC) consists of 12 members, including the seven members of the Federal Reserve Board of Governors and five of the 12 Federal Reserve Bank presidents. The chairman of the Board of Governors is traditionally elected chairman of the Committee. The president of the New York Federal Reserve Bank, also by tradition is elected the Commit. tee's vice chairman. All Federal Reserve Bank presidents attend Committee neetings and present their views, but only those who cur rently are nembers of the Committee are permitted to vote. In previous years, the four memberships that rotate among the Bank presidents were held for one-year terms comnencing March 1 of each year In 1989 , however, the nemberships were only for 10 months so that starting in 1990, the one-year terms would be on a calendaryear basis. The president of the New York Federal Reserve Bank is a permanent voting menber of the Commitiee.

Members of the Board of Governors at the beginning of 1989 included Chairman Alan Greenspan, Vice Chairman Manuel HI Johnson, Wayne K. Angell, $1 \mathrm{r}$ Robert Heller, Edward W. Relley, John P. LaW are and Martha R. Seger. Mr. Heller resigned as a member of the Committee during the year His position was not filled during 1989 .

The following Bank presidents voted at the meeting on February 7.8, 1989 . E Gerald Corrigan New York), Robert P. Black (Rich. mond), Robert P. Forrestal (Atlanta), W. Lee Hoskins (Cleveland) and Robert T Parry (San Franciscol. In March, the Conmittee nember. ship changed and the presidents voting posi. tions were filled by E, Gerald Corrigan (New York), Roger Guffey (Kansas City), Silas Keehn (Chicago), Thomas C. Melzer (St. Louis) and Richard f. Syron (Boston).

The Committee met eight times at regularly scheduled meetings during 1989 to discuss economic trends and decide the future course of open market operations? As in previous years, telephone consultations occasionally were held between scheduled meetings. At the end of each scheduled neeting, a direc. tive was issued to the Federal Reserve Bank of New York. Bach directive contained a short summary of economic developments, the general economic goals sought by the Committee, its long run monetary growth objectives, and instructions to the Manager for Domestic Operations at the New York Bank for the conduct of open market operations during the new intermeeting period These instructions were stated in terms of the degree of pressure on reserve positions to be sought or maintained. The reserve conditions stated in the directive were deemed consis tent with specific short-term growth rates for M2 and M3 which, in turn, were considered consistent with desired long run growth rates for these nonetary aggregates. The Committee also speeified intermeeting ranges for the federal funds rate. These ranges provided one mechanism for initiating consultations between meetings whenever it appeared that the constraint on the federal funds rate was inconsistent with the objectives for the behavior of the monetary aggregates.

The Manager for Domestie Operations has the primary responsibility for formulating plans regarding the timing types and amounts of daily buying and selling of securities in fulfilling the Committee's direetive Each norning the Manager and his staff plan the open market operations for that day: This plan is developed on the basis of the Committee's directive and the latest develop. ments affecting money and credit market conditions, the growth of monetary aggregates, and bank reserve conditions. The Manager also consults with the Board's staff. Prevailing market conditions and open narket operations that the Manager proposes to exe. cute are discussed each morning in a telephone conference call involving the staff at the New York Bank, one voting president at 
another Reserve Bank and staff at the Board. Other nembers of the Commettee may par ticipate and are informed of the daily plan by internal memo or wire.

The directives issued by the Committee and a summary of the discussion and reasons for Committee actions are published in the 'Record of Policy Actions of the Federal Open Market Committee" The "Record" for each meeting is released a few days after the next scheduled Committee meeting. It subsequent. ly appears in the Federal Reserve Bulletin. In addition, 'Records' for the entire year are published in the annual report of the Board of Governors. The record for each meeting in 1989 included:

(1) a staff summary of recent economic developments-such as changes in prices, employment, industrial produc: tion and components of the national accounts and projections of general price, output and employment developments for the year ahead;
(2) a summary of recent international financial developments and the U.S. foreign trade balance:

(3) a summary of open market operations, growth of the monetary aggregates and bank reserves and money market conditions since the previous meetings:

(4) a summary of the Commitree's discussion of the current and prospective. economic and financial conditions:

(5) a summary of the nonetary policy discussion of the Committee:

(6) a policy directive issued by the Commit tee to the Federal Reserve Bank of New York;

(7) a list of the menbers' votes and any dissenting comments; and

(8) a description of any actions regarding the Conmittee's other authorizations and directives, and reports on any ac: tions that might have occurred between the regularly scheduled meetings. first half of the year, the Committee decides whether to adjust or retain its target for the current year and establishes tentative targets for the following year. Shortly after the July meeting, a report of the Committee's decisions is submitted to Congress. Table 1 summarizes the Committee's long-run monetary growth objectives for 1989 as reported to Congress.

As was the case in the previous two years, the Committee did not establish a target range for M1 in 1989. The Committee believed that the unpredictable relation of $\mathrm{M} 1$ to economic activity and prices did not warrant reliance on this aggregate as a guide to the implementation of monetary policy. ${ }^{2}$

To underscore its commitment to resist future inflationary pressures and to make progress toward reasonable price stability, the Committee reaffirmed the 1989 targets for $\mathrm{M} 2$ and $\mathrm{M} 3,3$ to 7 percent and $31 / 2$ to $7 \frac{1}{1} / 2$ percent, respective- ly, that had been set tentatively in July $1988 .{ }^{3}$ These target ranges for M2 and M3 were 1 and $1 / 2$ percentage points, respectively, lower than those established for 1988.

The Committee also decided to maintain the 4 percentage-point spreads between the upper and lower bounds of the target ranges for the two broad monetary aggregates. Until two years ago, this spread had been 3 percentage points. The wider ranges were adopted in 1988 when the Committee concluded that the relations of M2 and M3 growth to economic growth and inflation had become considerably more variable and, therefore, that estimates of growth rates for these aggregates that would be consistent with the Committee's objectives for the economy were subject to greater uncertainty. Forecasting the appropriate growth rates was made more difficult by the Committee's uncertainty about the impact of future developments on thrift institutions and the subsequent effect on the 
Table 1

The FOMC's Long-Run Operating Ranges

\begin{tabular}{|c|c|c|c|}
\hline Date of meeting & Target period & 12 & Mo \\
\hline $\begin{array}{l}\text { June } 29.30,19881 \\
\text { february } 7,8,19892 \\
\text { July } 56,1989\end{array}$ & 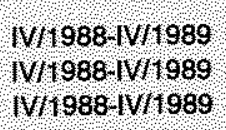 & $\begin{array}{l}3.7 \% \\
\text { reaffined } \\
\text { reafirned }\end{array}$ & $\begin{array}{l}3,5,75 \% \\
\text { reaffirmed } \\
\text { reaftrmed }\end{array}$ \\
\hline wily $5-6,19893$ & W/ $989-1$ W 1990 & $37 \%$ & $3,575 \%$ \\
\hline
\end{tabular}

1MS. Seger dissented. She wanted to retain the 48 percent target ranges for M2 and M3 at that tine in light of the uncertainty about the economic outlook.

2 M. Hoskins dissented. He believed that noney growth should be toward the low end of the ranges if any reasonable progress were to be made in reducing hilation, in his view, establishing bwer target ranges would emphas ize the System's perseverance in reducing infla. tlovary pressures.

3 Mr. Keehn dissented. He tavored reducing the larget ranges to communicate the System's adherence to is antintlationary comminent.

growth of the monetary aggregates. ${ }^{4}$ The wider target ranges were intended to give the Committee leeway to achieve its long-run objectives of maximum sustanable economic growth and, eventually, price stability.

By the early July meeting, M2 and M3 were growing at rates at or below the lower bounds of their respective target ranges. Through June, M2 growth was estimated to be 1 percentage point below its range and M3 growth was estimated to be at the lower end of its range. Nevertheless, in the context of recent declines in market interest rates, the Board's staff forecasted that the stronger growth exhibited by these aggregates since the middle of May would continue, thereby bringing the growth rates of $\mathrm{M} 2$ and $\mathrm{M} 33$ comfortably within their target ranges by the fourth quarter. Because it believed that these expected growth rates would
Table 2

\section{Target Ranges and Actual Money} Growth in 1989

\begin{tabular}{|c|c|c|}
\hline Aggregate & Target ranger & Actual \\
\hline 112 & $\begin{array}{l}3.7 \% \\
3.5 .7 .5\end{array}$ & $\begin{array}{l}4.6 \% \% \\
3.3\end{array}$ \\
\hline
\end{tabular}

The target period for M2 and M3 growth is front W/988 to IV1989.

be compatible with its objectives for economic growth and progress toward price stability, the Committee reaffirmed its 1989 targets for M2 and M3 in the July Report. ${ }^{5}$
4Record (May 1989), p. 357. The wide range of possible etfects of future developments on thrift institutions and subsequent effects on money growth made the staff's money growth forecasts subject to considerable uncertainty. See Garfinkel (1989) for a discussion of the Committee's motivation for adopting the wider $M 2$ and M3 target ranges.
5Report (August 1989), pp. 528-29. Also see Record (October 1989), p. 693. It should be noted that all money growth rates reported here are revised figures, as of February 21, 1990, incorporating the February 1990 benchmark and seasonal revisions. The reported numbers for $\mathrm{M} 2$ growth also incorporate the redefinition of M2 that now includes thrift overnight repurchase agreements. 


\section{Figure 1 \\ Money Stock (M2)}

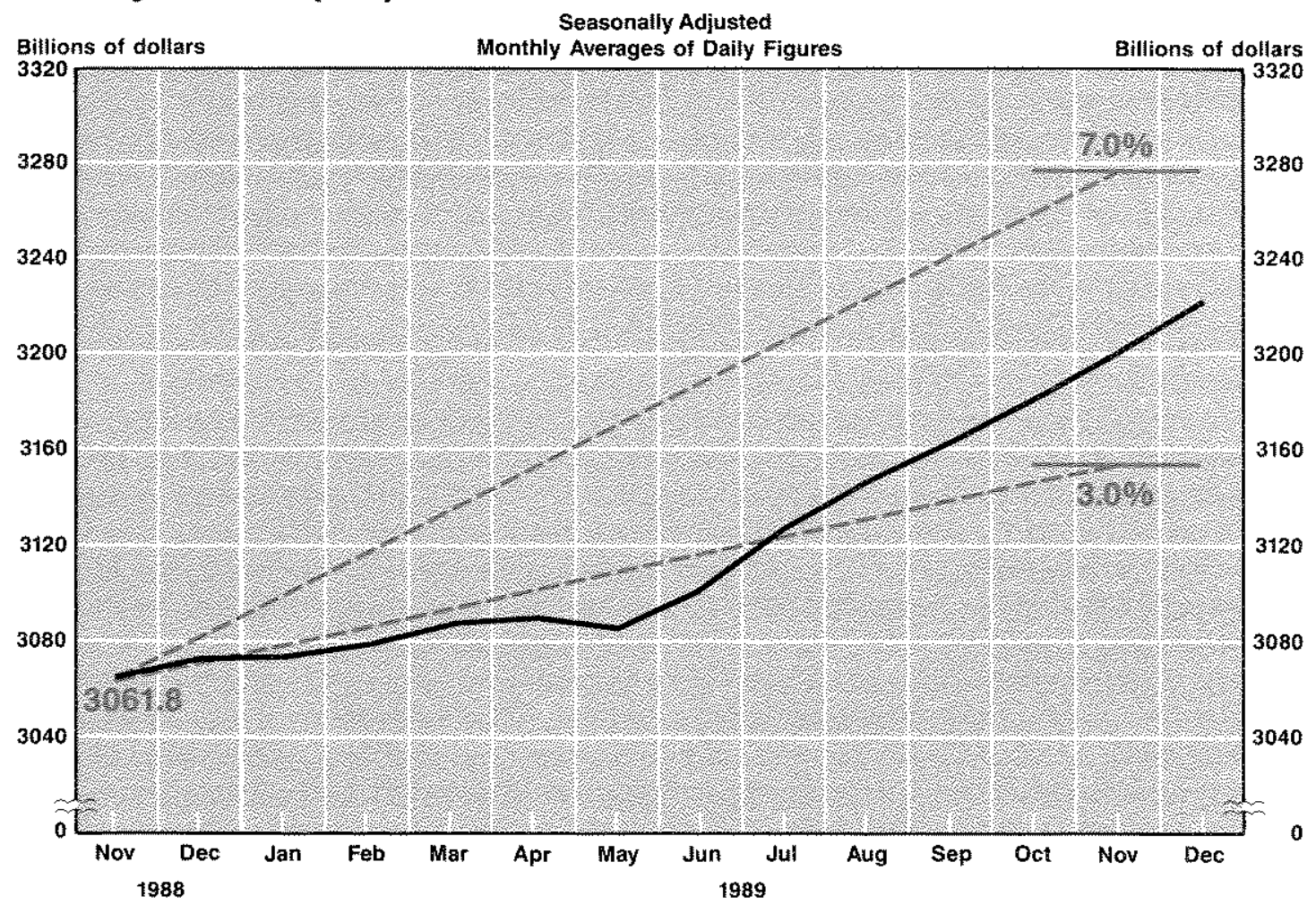

The July Report also stated that the 1989 target ranges for $\mathrm{M} 2$ and $\mathrm{M} 3$ would be extended tentatively to 1990 . While the Committee recognized that a further reduction in the growth of the monetary aggregates would be more consistent with attaining price stability over time, many members believed that more rapid M2 growth might be necessary to promote reasonable growth in economic activity in 1990. Reductions in the ranges would increase the likelihood of making policy appear unpredictable by increasing the possibility of a reversal later or of having to tolerate growth rates exceeding the lower target ranges. The targets for 1990 could be adjusted in February, if appropriate. ${ }^{6}$

Table 2 indicates that the actual rate of growth in M2 during $1989,4.6$ percent, was close to the middle of its target range. The actual rate of growth in M3, 3.3 percent, however, was slightly below the lower bound of its target range. The growth rates varied considerably during the year as illustrated in figures 1 and 2, which show the monthly averages of (revised) daily figures, respectively, for M2 and M3. As discussed below, these variations had some influence on the Committee's short-run policy decisions.

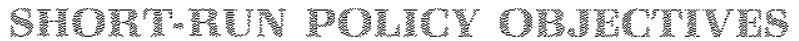

Each year, the Committee holds eight regularly scheduled meetings to review incoming data and assesses the current economic environment and the prospects for the future course of the economy. Based on this information, the members determine what changes, if any, should be made in short-run monetary policy to achieve the Committee's long-term goals. At the close of each meeting, the Committee issues a domestic policy directive to the Federal Reserve Bank of New York. This directive serves as the basis for day-to-day implementation of policy in the inter-

Gecord (October 1989), pp. 693-94. 


\section{Figure 2 Money Stock (M3)}

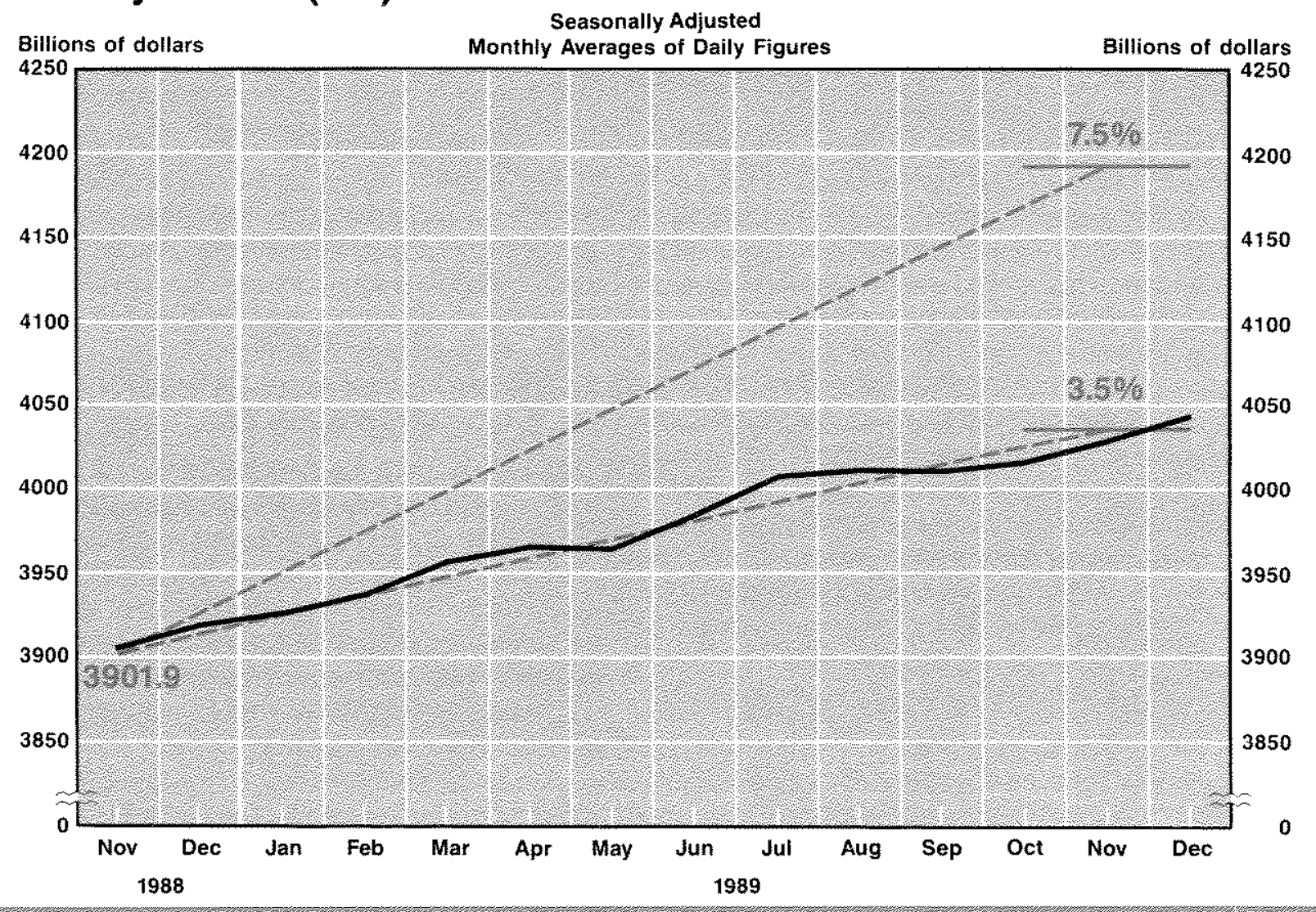

meeting period by the Manager for Domestic Operations, who is responsible for executing the directives. As usual, the directives issued during 1989 primarily emphasized the degree of restraint on reserve positions (maintain, increase or decrease) that was considered by the members to be consistent with the Committee's money growth targets and goals for the economy.

Maintaining the approach used since October 1982, the Federal Reserve System followed a borrowed-reserves operating procedure. This procedure translates the degree of reserve restraint specified in the directive into a target for borrowed reserves (reserves borrowed from the Federal Reserve Banks). For example, under this procedure, an instruction to increase the degree of pressure on reserve positions would imply a higher target for borrowed reserves (adjustment plus seasonal borrowings) and a higher federal funds rate for a given discount rate.

Toward the end of 1988 and continuing into 1989 , however, this operating procedure was complicated by the unstable relation between the demand for borrowed reserves and the federal funds rate. Specifically, the willingness of depository institutions to borrow reserves, for given federal funds and discount rates, was declining unexpectedly. At the December 1988 meeting, the Committee considered the possibility of adjusting the operating procedure to shift the focus
The positive relation between borrowed reserves and the federal funds rate follows from economic theory. Specifically, the demand for borrowed reserves (the "borrowings function") is negatively related to the opportunity cost of borrowing from the discount window. This cost equals the spread between the discount rate (the interest rate paid by depository institutions for borrowed reserves from Federal Reserve Banks) and the federal funds rate (the interest rate paid for reserves borrowed from other depository institutions). For a discussion of the implementation of monetary policy under the borrowed-reserves operating procedure, see Gilbert (1985) and Thornton (1988). 
of policy implementation to the federal funds rate, but the members generally agreed that adhering to the current procedure would be appropriate given its advantages. ${ }^{s}$ Nevertheless, the Committee believed that the uncertainty about the relation of borrowings to the federal funds rate warranted flexibility in implementing monetary policy. Hence, some of the directives issued in 1989 were written with the understanding that flexibility would be permitted in conducting day-to-day policy so as to achieve the Committee's objectives, given the changing conditions in the market for borrowed reserves.

Furthermore, the Committee maintained the flexibility in short-run policy adopted in previous years because of uncertainty about the relations of monetary aggregate growth to output growth and inflation. The Committee believed that shortrun policy should be decided not only on the basis of the behavior of the monetary aggregates, but on the basis of indicators of inflationary pressures, economic growth and the changing conditions in domestic financial and foreign exchange markets. ${ }^{9}$

In addition to the desired degree of reserve pressure, the directives indicated potential modifications in the intermeeting period, and the expected growth rates of M2 and M3 conditional on the desired reserve restraint. Each directive also established a monitoring range for the federal funds rate. The Chairman could initiate a Committee consultation if, during the intermeeting period, the federal funds rate were to move out of that range. Over the past several years, however, such consultations have been initiated because of unexpected economic and financial developments.

The following discussion reviews each FOMC meeting chronologically. It focuses on the important economic developments of 1989, show- ing how they influenced the Committee's formulation of short-run policy objectives. Table 3 summarizes the directives issued in 1989. Table 4 shows the actual (revised) intra-year growth rates in $\mathrm{M} 2$ and $\mathrm{M} 3$, as well as those rates ex. pected by the Committee.

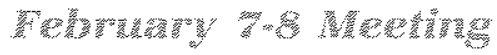

Economic data reviewed at this meeting suggested that, abstracting from the direct impact of the previous year's drought, economic growth continued at a fast pace. The marked increase in total nonfarm payroll employment in January was widespread and the civilian unemployment rate of 5.4 percent was only marginally above December's rate of 5.3 percent. Industrial production rose sharply in December and January and the industrial capacity utilization rate in January exceeded its average rate over the fourth quarter of the previous year. ${ }^{10}$

Indicators of inflation at the beginning of 1989 showed hardly any change from 1988. Although the producer price index rose sharply in December, the behavior of the consumer price index, excluding food and energy, was perceived to be in line with its pattern in 1988." Labor costs, particularly wages and salaries, rose appreciably faster than one year earlier, however.

As instructed by the Committee's last directive in 1988 , the degree of pressure on reserve positions was increased at the beginning of the pren vious intermeeting period. During this period, the average level of adjustment plus seasonal borrowings was slightly above $\$ 500$ million and the federal funds rate rose to about 9 percent from about $8 \frac{1}{2}$ percent. As other market interest rates rose, the growth of the broader monetary aggregates, particularly $\mathrm{M} 2$, weakened in January. ${ }^{12}$

in December and January. The Board's measure of the total industry capacity utilization rate in January was 84.3 percent, up from the previous quarter's average of 84.1 percent.

1:lbid., pp. 353-54. The annual growth rate of the seasonally adjusted producer price index for finished goods was 3.3 percent in December, while the seasonally adjusted consumer price index for all urban consumers rose at an an" nual rate of 4.1 percent. Excluding food and energy, the latter index rose at an annual rate of 4.9 percent.

relbid., p. 354. In January, $M 2$ rose sluggishly at an annual rate of 0.5 percent and $M 3$ rose at an annual rate of 2.4 percent.

10Record (May 1989), p. 353 . Industrial production rose at annual rates of 4.4 percent and 3.5 percent, respectively, 
Table 3

The FOMC's Short-Run Operating Ranges for 1989

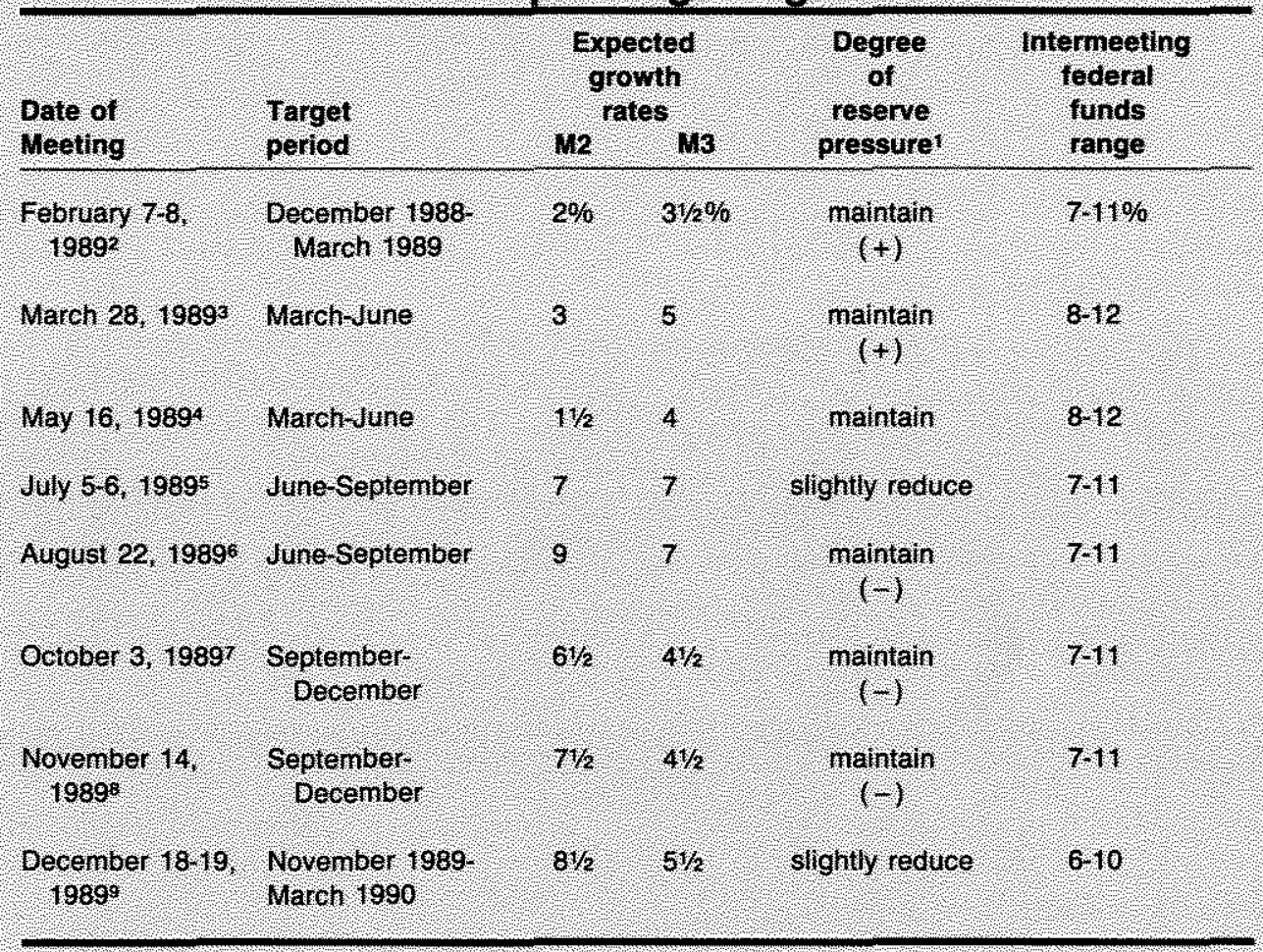

IA' + ' indicates an expectation that during the intermeding perlod developments were nore likely to warrant an adjustment toward festrant than toward ease. The opposite is true for a 1:

ZMessrs. Hoskins and Parry dissented. Mr. Hoskins thought that an immediate nove toward greater monetany restraint would be appropriate to put policy on a course loward price stability In the longer run. Mr. Parry stressed hat, since economic growth had exceeded its long-run, honinilationary rate, inflationary plessures were already hcreasing. In their view, without an inmediate increase in restrain on reserve positions, inllationary pressures would intensity and thereby make the task of achieving the Commitee's anthinflationary goal more difficult

aMs. Seger dissented, Athough maintaining the existing degree of reserve pressure was ap. propriate in her view, she believed that the blas toward monetary restraint was undesirable in Iight of the lagged effects of apprectable tightening that had been undertaken earlier along with current indications of slower economic growth.

4. Melzer dissented, advocating prompt action to ease the degree of reserve pressure slight by Pointing to the past wo years of slow money growth, the stressed that the current high in flation would be reduced eventually and that, in the absence of an easing action, the risks of a recession would be augmented. Feaching the System's neh inflationary goal would be hampered it, in lesponse to a recession, monetan policy were to aim at a quick recovery.

5Ms, Seger dissented She tavered a greater degree of easing that, in her view, would be necessary to promote reasonable economic growth in the following years.

GMr Guffey dissented. Ho could accept an unchanged policy But he believed that a directive that was blased toward ease was not appropiate given that the chances of a weakering of the economic expansion appeared 10 be essentially the same as the chances of a strengthen ing of the expansion while, in his view, the current and expected future inflation rates were not acceptable. Futhermore, such a bias toward ease could lessen contidence in the Commit. tee's commitment to achieve long run price stablity 
Table 3 continued

\section{The FOMC's Short-Run Operating Ranges for 1989}

Mr Guftey and Ms. Seger dissented. Mr. Guffey belleved that the bias loward easing resenve pressure in the intermeeting period was not appropiate, for he was concerned that inflation in the future would remain unacceptably high. Ms. Seger pointed to sighs of a weakening economy and indicated that some immediate easing would be necessany to sustain the expansion She believed that such a policy would be consistent with the committee's long terin ob jective of price stability.

QMS. Seger dissented In her view, signs of a weakening in economic ac ivity, particularly in the nanufacturing sector, varranted an mmediate further easing of reserve pressure:

Messis. Angell and Melzer dissented, favoing an unchanged policy Mr. Angell believed that a policy of easing reserve restraint based on recent indications of a weakening in economic ac. tivity was hot warranted. 10 the extent that the impact of monetary policy is realized with a lag, in his view, policy should be based on fomard looking indicators of economic activity. Further, he believed that an easing of pollcy at this time, given past policy, could have an un tavorable impact on the System's credibility in pursuing a goal of price stability Mr. Melzer noted that policy had been eased considerably over the past six months and, given the suff. cient liquidity in the econony, he did not belleve that further easing was desirable. He also was concerned that, in light of the current and projected growth of the nonetary aggregates, easing of policy at this time wolld hamper the Systern's ability 10 make progress toward its longtern goal of price stability.

Table 4

\section{Actual and Expected Rates of Money Growth}

\begin{tabular}{|c|c|c|c|c|}
\hline \multirow[b]{2}{*}{ Period } & \multicolumn{2}{|c|}{$1 / 2$} & \multicolumn{2}{|c|}{$1 / 3$} \\
\hline & Expected & Actual & Expected & Actua \\
\hline $\begin{array}{l}\text { December } 1988 . \\
\text { March } 1989\end{array}$ & $2 \%$ & $180 \%$ & $31 / 2 \%$ & $4.0 \%$ \\
\hline 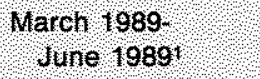 & $1 / 2,3$ & 19 & 45 & 29 \\
\hline June 1989 S & 79 & 8.2 & 7 & 27 \\
\hline $\begin{array}{l}\text { September } 1989 \\
\text { Decenber } 19893\end{array}$ & $61 / 271 / 2$ & 77 & $4 \%$ & 32 \\
\hline
\end{tabular}

At the May 16 neeting, the Commitee lowered its expectation for M2 and M3 $101 / 2$ percent and 4 percent respectively, from 3 percent and 5 percent.

At the August 22 meeting, the Committee s expecta. tions for M2 growth were evised from 7 percent to 9 percent.

The Committee's expectation for N2 growth was tevised from $6 / 2$ percent $107 / 2$ percent at the November 14 meeting
The Board's staff expected that economic activity would continue expanding in 1989 at a more modest pace than it had in 1988. Assuming that monetary policy would attempt to contain the inflationary pressures predicted by the staff, the staff's forecast pointed to pressures in financial markets that would tend to dampen growth in domestic spending. In addition, the staff expected that foreign demands would provide less of an impetus to domestic output growth than in 1988. Given the relatively low margins of unutilized labor and high capacity utilization rates, the staff predicted additional price pressures in the current year. ${ }^{13}$

In the Committee's discussion of policy implementation, many members indicated that economic growth appeared to be balanced, but most members expressed concerr about the prospect of greater inflation. A majority of the members, however, saw no need for an immediate change in policy in light of the data available for review, the appreciable recent tightening in policy and their perception that the credibility of the Committee's commitment to fight inflation was high. These members were willing to wait for additional evidence confirming their fears of greater inflation before tightening policy further. ${ }^{14}$

13 bid., pp. 354-55.

14lbid., p. 358. 
Some members advocated an immediate tightening of reserve conditions to contain any future inflationary pressures. In their view, without immediate action, the task of achieving price stability could become more difficult. Other members expressed concern that additional pressure on reserve positions could aggravate the financial conditions of many thrift institutions and highly indebted firms. In addition, further restraint might add to the recent unusual strength of the dollar. ${ }^{15}$ Although the recent slow growth of the monetary aggregates was thought to indicate future restraint on price pressures, some members cautioned that a shortfall from targeted ranges would be a matter of concern. ${ }^{16}$

At the end of the meeting, the Committee adopted a directive that called for an unchanged degree of pressure on reserve positions, with a possible increase or decrease depending on forthcoming information about inflationary pressures, the strength of business expansion, growth in the monetary aggregates and developments in foreign exchange and domestic financial markets. As table 3 indicates, however, there was a "bias" toward restraint, and the members called for "remaining alert to potential developments that might require some firming during the intermeeting period."17 In light of the continuing uncertainty about the relation of the demand for borrowed reserves to the federal funds rate, the directive was issued with the explicit understanding that flexibility would be needed in implementating monetary policy. Given the contemplated reserve conditions, the Committee expected the annual growth rates for M2 and M3 to be around 2 percent and $3 \frac{1 / 2}{2}$ percent, respectively, from December to March. The directive left the range for the federal funds rate unchanged at 7 to 11 percent. ${ }^{18}$

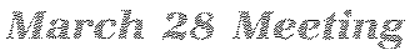

During the intermeeting period, additional pressure was placed on reserve positions, in light of incoming data indicating greater inflationary pressures. Also, on February 24, the Board of Governors approved a 50 basis-point increase in the discount rate to 7 percent. From the time of the increase in the discount rate to this meeting, the federal funds rate rose nearly 75 basis points to slightly above $9^{3 / 4}$ percent. Other market interest rates, especially those on shorter-term securities, also rose. As the demand for borrowed reserves appeared to fall, the borrowings assumption was lowered as a technical adjustment. The average of adjustment plus seasonal borrowings during the six-week period just before this meeting fell to about $\$ 450$ million. Although the monetary aggregates appeared to gain some strength in February and March, their growth was viewed as sluggish relative to that in the previous year. ${ }^{13}$

The information available for review at this meeting suggested that economic activity expanded considerably in the first quarter. Total nonfarm employment advanced sharply in February and the civilian unemployment rate fell to 5.1 percent. Only part of the employment gain was attributed to the unusually mild weather during the first two months of the year. ${ }^{20}$

There were, however, indications of a slight weakening of the economic expansion. For example, preliminary data suggested that industrial production remained flat and capacity utilization rates fell slightly in February. ${ }^{21}$ Furthermore, growth in consumer spending slowed in the first two months of the year from its vigorous pace during the last quarter of 1988. Although the data indicated that the nominal U.S. mer. chandise trade deficit improved in January, the value of exports fell. But the observed net rise of the trade-weighted value of the dollar over the intermeeting period was attributed largely to the rise in market interest rates stemming, in part, from restrictive actions taken during that period. ${ }^{22}$

\footnotetext{
15lbid., pp. 358-59. As a measure of the relative strength of the dollar in foreign exchange markets, the Federal Reserve Board constructs a trade-weighted index using the currencies of Belgium, Canada, France, Germany, Italy, Japan, the Netherlands, Sweden, Switzerland and the United Kingdom. The trade-weighted index rose about 6 percent over the intermeeting period.

16bid.

17 bid., p. 359.

18/bid., pp. 359-60.
}

${ }^{19}$ Record (July 1989), p. 503. M2 rose at annual rates of 1.8 percent and 3.5 percent, respectively, in February and
March. M3 rose at annual rates of 3.3 percent and 6.2 percent, respectively, during those same two months.

zolbid, p. 502. The civilian unemployment rate in February has been revised upward to 5.2 percent.

21 lbid. Revised data indicate that industrial production actually fell in February at an annual rate of 2.5 percent.

z2lbid., pp. 502-03. The trade-weighted index of the value of the dollar in foreign exchange markets rose approximately 1.5 percent over the intermeeting period. 
Price pressures appeared to gain some strength in the first two months of 1989. The observed increases in price indexes were thought to be due chiefly to energy and food prices. Even excluding these components, however, the producer and consumer price indexes rose sharply in January and February. ${ }^{23}$

The Board's staff predicted that the pace of economic expansion would slow considerably from the pace in 1988. The forecast assumed that monetary policy would restrain the inflationary tendencies in the economy. Such a policy could put additional pressure on financial markets and involve slower growth in consumer spending and business fixed investment. ${ }^{24}$

The members generally agreed that, in light of mixed evidence about the strength of economic expansion and the uncertain prospects for the future, an unchanged policy would be acceptable. Some members, who preferred an immediate tightening of reserve conditions, believed that inflationary pressures could intensify given the apparent momentum in economic activity. These members, however, were willing to wait for additional information that tended to confirm their fears. Most members believed that the unusual strength of the dollar in foreign exchange markets would dampen price pressures. Furthermore, as suggested by earlier experience, the sluggish growth in the monetary aggregates lessened the likelihood that inflation could gain much strength in the future. ${ }^{25}$

As table 3 shows, the Committee adopted a directive that did not call for a change in policy but that permitted a policy adjustment during the intermeeting period more readily toward restraint than ease. Open market operations were to be conducted with some degree of flexibility because of the continuing uncertainty about the relation of the demand of borrowed reserves to the federal funds rate. Growth in $\mathrm{M} 2$ and M3 were expected to be around 3 per. cent and 5 percent, respectively, from March to
June. The intermeeting range for the federal funds rate was increased 1 percentage point to 8 to 12 percent, "in light of the tightening of reserves since the February meeting and the related increase in the federal funds rate." 26

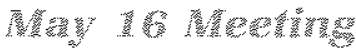

Aside from the slightly firmer reserve conditions due to the greater-than-expected reserve flows related to April tax payments, reserve conditions hardly changed in the intermeeting period. During this period, the average of adjustment plus seasonal borrowing rose to about $\$ 565$ million, while the rate at which federal funds traded rose slightly to around $9-7 / 8$ percent. Other market interest rates, especially short-term rates, fell over the intermeeting period, however. Estimated growth of the monetary aggregates was sluggish, with the cumulative growth of $\mathrm{M} 2$ since the fourth quarter of 1988 well below the lower bound of the Committee's target range and that of M3 just above the lower limit of its target range. ${ }^{27}$

Economic data reviewed at this meeting suggested that the expansion of economic activity had moderated in recent months. Growth in total nonfarm employment edged downward in March and April, while the civilian unemployment rate climbed from 5.0 percent in March to 5.3 percent in April. In addition, growth in con. sumer spending maintained the much slower pace established in the first part of the year relative to that in 1988 . Industrial production grew in April, but, from December to April, it grew more slowly than it had in 1988. Much of the April growth was attributed to an increase in automobile assemblies after a weak first quarter and a rebound in the output of other consumer goods. Although the total capacity utilization rate rose slightly in April, it remained below its January rate. ${ }^{28}$

There were indications, however, that the momentum in economic activity had not been en-

\footnotetext{
$23 \mathrm{lbid}$. The seasonally adjusted producer price index for finished goods rose at annual rates of $\$ 3.9$ percent and 7.8 percent, respectively, in January and February; excluding food and energy prices, if rose at annual rates of 6.2 percent and 7.2 percent, respectively, in January and February. Similarly, the seasonally adjusted consumer price index for all urban consumers rose at annual rates of 7.2 percent and 5.1 percent, respectively, during the first two months of the year; excluding food and energy, this index rose at annual rates of 5.9 percent and 4.8 percent.

$24 \mathrm{lbid}$., p. 504 .
}

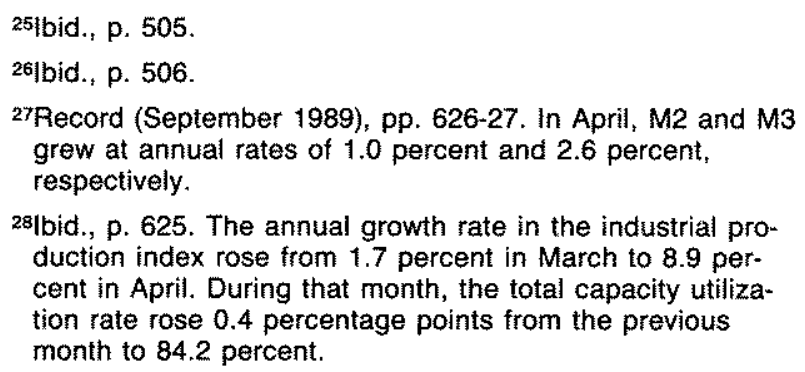
grew at annual rates of 1.0 percent and 2.6 percent, respectively.

28|bid., p. 625 . The annual growth rate in the industrial pro duction index rose from 1.7 percent in March to 8.9 percent in April. During that month, the total capacity utilization rate rose 0.4 percentage points from the previous month to 84.2 percent. 
tirely lost. Capital business spending rebounded after falling in the last quarter of 1988 . Further. more, although the nominal U.S. merchandise trade deficit widened in February the average deficit for the first two months of 1989 remained below that for the fourth quarter of 1988 , with the value of exports growing more rapidly than that of imports. Despite the slight deterioration in the external trade balance in February and the general downward movement in interest rates more recently, the dollar gained further strength in the intermeeting period. ${ }^{29}$

The recent behavior of the price indexes did not ease the members' fear of future inflation. Rather, price level movements were interpreted by the members as an indication that inflationary pressures were rooted deeply in the economy. Although the producer price index grew more slowly in March and April than in the earlier two months of the year, the consumer price index grew at a slightly faster pace in the first quarter of 1989 than in the previous quarter. Increases in food and energy prices contributed to the observed increases in mea sured inflation, but were not the sole driving force of the perceived upward trend in inflation. $^{30}$

The staff's projection changed little from that prepared for the previous meeting. Growth in economic activity was expected to be slower than in 1988. The forecast indicated that prices at both the consumer and producer levels would increase at somewhat faster rates in 1989. In the staff's view, monetary policy that attempted to contain such inflationary pressures, should they materialize, would imply greater pressure on financial markets. In addition to a continuation of sluggish growth in consumer spending, the staff expected that growth in business capital spending would retreat from its fast pace in the first quarter. ${ }^{33}$

Uncertainty about the impact of previous restrictive policy actions on inflation and the pace of economic growth dominated the discussion at this meeting. Whether monetary conditions were sufficiently restrictive to contain future inflationary pressures without precipitating an excessive slowing of economic growth remained unclear. Although one member believed that an immediate easing of reserve pressure would be both necessary and desirable to improve the prospects for adequate monetary growth to sustain the economic expansion, others feared the risks associated with such a policy-that is, of having to reverse the easing if the monetary aggregates were to accelerate unduly and price pressures were to intensify later. ${ }^{32}$

In the discussion about possible adjustments to monetary policy in the intermeeting period, most members agreed that no bias-either toward restraint or ease-would be appropriate. While one member believed that policy should be particularly alert to behavior of the monetary aggregates that could warrant some easing, others believed that the deeply rooted inflationary pressures called for a bias toward restraint. A number of members expressed concern that the absence of a bias toward restraint might give an incorrect signal that the Committee was moving away from its anti-inflationary commitment. ${ }^{33}$

At the end of this meeting, the Committee issued a directive that called for an unchanged degree of pressure on reserve positions. Depending on forthcoming information, a move to some restraint or ease would be acceptable during the intermeeting period. The Committee believed that continuing uncertainty about the relation of the demand for borrowed reserves to the federal funds rate warranted continuing flexibility in the implementation of monetary policy. The Committee expected that the contemplated reserve conditions would be consistent with $\mathrm{M} 2$ and $\mathrm{M} 3$ growing at $1 \frac{1}{1 / 2}$ and 4 percent annual growth rates, respectively, from March to June. The intermeeting range for the federal funds rate was kept at 8 to 12 percent. $^{34}$

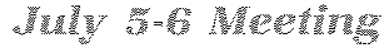

Late in the intermeeting period, incoming information tended to confirm earlier indications z9lbid. pp. 625-26. The value of the dollar relative to the other G-10 currencies appreciated about 4 percent over the intermeeting period.

30ibid., p. 626. The seasonally adjusted consumer price index for all urban consumers rose at annual rates of 6.1 percent and 8.1 percent, respectively, in March and April. Excluding food and energy prices, this price index rose 4.8 percent and 2.9 percent. The producer price index for finished goods, excluding food and energy, rose at annual rates of 2 percent and 1 percent.

31 bid., p. 627.

32/bid., pp. 628-29.

33lbid., p. 629.

${ }^{34}$ lbid. 
that the economic expansion had slowed so that the prospect of weakening inflationary pressures seemed more promising. Furthermore, the monetary aggregates continued to exhibit slow growth and the dollar had gained considerable strength earlier in the intermeeting period. Accordingly, a slight lowering of the pressure on reserve positions was sought. Before this easing, however, a technical upward revision had been made to accommodate unusual strength in seasonal borrowing. Over the six-week period ending June 27, the average of adjustment plus seasonal borrowings was around $\$ 550$ million, and the federal funds rate edged down to $9 \frac{1}{2}$ percent. Other market interest rates, especially those on long-term securities, also fell. The observed decline in the level of the broader monetary aggregates during May was interpreted as a reversal of the temporary rise in transaction accounts related to April tax payments. ${ }^{35}$

Confirming earlier evidence, the information avaitable for review at this meeting suggested that the economic expansion had slowed considerably from its pace in 1988. While the civilian unemployment rate fell to 5.2 percent in May, growth in total nonfarm employment was relatively weak. Preliminary data indicated that, in May, growth in industrial production was modest and the total capacity utilization rate had fallen back to its March level. ${ }^{36}$ While business capital spending appeared to make further gains in the second quarter, growth in consumer spending remained sluggish. Further, the significant improvement in the nominal U.S. merchandise trade balance during April stemmed chiefly from a considerable drop in imports with only a slight increase in exports. ${ }^{37}$

Price pressures persisted despite the indications of slowing economic expansion. Increases in food and energy prices, however, made large contributions to the increases in the producer price index and, to a lesser extent, in the con- sumer price index. ${ }^{38}$ Nevertheless, the growth in labor costs appeared to have maintained its momentum from the middle of 1988 .

The Board's staff revised its forecast for economic growth in the second half of the year downward from that made earlier in the year. The staff's forecast now suggested less inflation than was previously expected, though more inflation than had been experienced in 1988, and continued growth in labor costs in 1989. This inflation outlook took account of the persistent strengthening of the dollar that was expected to dampen inflationary pressures. The forecast, however, also pointed to slightly more favorable inflationary conditions in 1990 than were previously expected. ${ }^{39}$

In the context of a weaker outlook for economic growth, the members generally believed that a further reduction in the degree of pressure on reserve positions would be appropriate. Although there was some disagreement about the timing and the extent of such easing, most members agreed that they could accept an immediate slight reduction in reserve pressure. In the view of many members, a greater move toward ease could have an undesirable effect on inflationary expectations, thereby putting upward pressure on long-term interest rates. A substantial move toward ease might have to be reversed if inflationary pressures subsequently intensified.

Nearly all believed, however, that the easing should be implemented immediately given the slowing pace of economic expansion and the sluggish growth of the broader monetary aggregates. Although some members preferred a directive that was biased toward restraint to maintain the credibility of the Committee's anti-inflationary commitment despite the easing of policy, others advocated a bias toward ease to communicate the Committee's belief that the risks
35Record (October 1989), p. 691. Revised data indicate that in May, M2 dectined at an annual rate of 1.6 percent and M3 rose sluggishly at an annual rate of 0.2 percent. In June, the annual growth rates in $M 2$ and $M 3$ rebounded to 6.5 percent and 6.0 percent, respectively

36|bid., p. 689 . Revised data indicate that the industrial production index fell at an annual rate of 0.8 percent in May, while the total capacity utilization rate in May, which fell to 84.0 percent from 84.2 percent in April, was above the rate of $\mathbf{8 3 . 8}$ percent in March.

37bid., pp, 689-90. Despite the improvement in the external balance, the value of the dollar relative to the other $\mathrm{G}-10$ currencies fell on net about 3 percent over the in- termeeting period. After having risen sharply in the first half of the period, the trade-weighted index of the value of the dollar declined appreciably over the second half.

3albid., p. 690. But, even excluding food and energy prices, the seasonally adjusted producer price index advanced sharply, rising at annual rates of 7.2 percent and 8.2 percent, respectivey, in May and June. Similarly, the seasonally adjusted consumer price index, excluding food and energy components, rose 5.8 percent and 2.8 percent, respectively, in May and June.

39lbid., p. 691. 
of an undesirable shortfall in economic growth were substantial. Most members agreed that, given the prevailing uncertainty, they could accept an unbiased directive. ${ }^{40}$

As table 3 shows, the directive issued by the Committee at the close of this meeting called for an immediate and slight reduction in the degree of reserve pressure. Further easing or some tightening was considered to be appropriate depending on future developments. Conditional on the contemplated reserve conditions, the Committee expected that both M2 and M3 would grow at an annual rate of 7 percent from June to September. Given the easing of reserve pressure in early June and that specified in this directive, the monitoring range for the federal funds rate was lowered 1 percentage point to 7 to 11 percent. $^{41}$

\section{A}

As instructed by the Committee at the close of the previous meeting, the degree of pressure on reserve positions was reduced at the beginning of the intermeeting period. Toward the end of July, the degree of reserve restraint was eased further, in light of incoming data that indicated a continued weaker economic expansion and a slight reduction in inflationary pressures. At the beginning of the intermeeting period, however, the assumed level of adjustment plus seasonal borrowing was increased as a technical revision prompted by a projected rise in seasonal bor. rowing during the summer months. Hence, the average of adjustment plus seasonal borrowings over the six-week period ending August 22 rose to approximately $\$ 600$ million despite the easing actions taken during this period. Nevertheless, the federal funds rate fell 50 basis points to around 9 percent. Preliminary data indicated that, in July, growth in the monetary aggregates gained considerable strength, which appeared to continue into August. ${ }^{42}$
The data reviewed at this meeting reinforced the earlier evidence of a moderate economic expansion. The data, however, suggested less weakness in the expansion than they had toward the end of July. Nonfarm payroll employment made considerable advances in June and July. The civilian unemployment rates for these months, 5.3 percent and 5.2 percent, respectively, were close to the average unemployment rate during the first five months of the year. In addition, preliminary data indicated that industrial production rebounded in July after having fallen in May and June. ${ }^{43}$ Industrial capacity utilization maintained its high rate, although the rate for manufacturing in July was well below that in January. Moreover, growth in consumer spending in the second quarter was stronger than originally estimated, and the observed narrowing of the nominal U.S. merchandise trade deficit reflected not only a notable decline in the value of imports, but a marked jump in the value of exports. ${ }^{44}$

The recent behavion of price indexes sug. gested somewhat less inflation primarily because of appreciable declines in food and energy prices. Preliminary data indicated that, while the consumer price index rose in both June and July, the increases were modest, and the producer price index for finished goods fell. ${ }^{45}$ Wage growth over the past several months did not appear to deviate from previously established trends.

The staff expected that, during the rest of the year, growth in the nonfarm economy would maintain its pace from the first half of the year and then grow more slowly in 1990 . With interest rates falling since the spring and the recently observed substantial job gains, consumer spending was expected to exhibit greater strength in the coming months. The forecast indicated that business capital spending would continue to make a large contribution to economic growth. Partly because of the earlier strength- 401bid., p. 695 .

411bid., p. 696. In this instance, there was no mention of the uncertainty revolving around the relationship between borrowings and the federal funds rate and, therefore, no reference to flexibility in monetary policy implementation.

42Pecord (December 1989), p. 813. Growth in M2 accelerated from 6.5 percent in June to 10.3 percent in July. The annual growth rate in M3 rose less dramatically from 6.0 percent in June to 6.9 percent in July.

albid., p. 812. Revised data, however, indicate that industrial production rose at an annual rate of 3.4 percent in
June and fell at an annual rate of 0.8 perceni in July. The July civilian unemployment rate has been revised upward to 5.3 percent.

44 bid., pp. 812-13.

$45 \mathrm{lbid}$, p. 813 . The seasonally adjusted producer price index for finished goods rose at an annual rate of 1.1 percent in June and fell at an annual rate of 4.1 percent in July. But, excluding the food and energy prices, this index rose at an annual rate of 8.2 percent in June and fell at an annual rate of 1.9 percent in July. 
ening of the dollar in foreign exchange markets, however, foreign trade was not expected to be a significant source of economic growth. In addition, although expected further declines in food and energy prices suggested that price pressures could weaken in the coming quarter, the staff expected no substantial improvement in the inflationary trend through $1990 .{ }^{46}$

With evidence that the economic expansion had stabilized at a "provisionally acceptable pace" and that inflationary pressures were not gaining strength, the members generally believed that the current degree of reserve pressure should be maintained, at least in the early part of the intermeeting period. An unchanged course for policy was also justified by the observation that growth in M2 and M3 recently had gained sufficient strength to place these aggregates in their target ranges. ${ }^{47}$

Discussing possible adjustments in policy durm ing the intermeeting period, many members expressed the belief that, if future developments were to warrant a change in policy, the direction of change would most likely be toward some ease. Some members, however, preferred not to incorporate such a presumption in the directive. In their view, the "risks to the economy were more evenly balanced." That is, the direction of change in policy justified by developments in the intermeeting period was just as likely to be toward restraint as it was toward ease. Further, these members believed that a bias toward ease could "lead to a misreading of System policy in the context of an unacceptably high rate of inflation."48

The directive issued at the end of this meeting specified no immediate change in policy, as table
3 indicates. Despite some members' reservations, the directive included a bias toward ease. The Committee expected M2 and M3 to grow at annual rates of about 9 percent and 7 percent, respectively, from June to September. The intermeeting range for the federal funds rate was kept at 7 to 11 percent. ${ }^{49}$

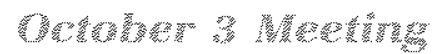

Over the intermeeting period, reserve conditions displayed no noticeable change. The average of adjustment plus seasonal borrowing during the four weeks ending September 20 fell slightly to about $\$ 550$ million, and the federal funds rate fluctuated within a narrow range centered around 9 percent. Although M2 growth was strong, M3 growth had unexpectedly lost some of its strength in August and preliminary data suggested that this slower growth had continued into september. ${ }^{50}$

The data available for review at this meeting reaffirmed earlier projections, that the economic expansion had continued at a moderate pace in the third quarter. Nonfarm payroll employment generally made considerable advances after allowing for the effects of strike activity. Nevertheless, there were hardly any job gains in manufacturing industries, and the civilian unemployment rate in August and September was close to $5^{1 / 4}$ percent. Further, after increasing moderateIy in August, industrial production fell slightly in september. ${ }^{51}$ The industral capacity utilization rate, however, remained relatively high. While growth in business capital spending seemed to have slowed in the third quarter, consumer spending continued to exhibit considerable strength. With the value of imports declin-

\footnotetext{
${ }^{46} \mathrm{lbid}$, p. 814. Over the intermeeting period, the value of the dollar relative to the other $\mathrm{G}-10$ currencies rose ap proximately 2.7 percent, almost offsetting the previous net decline. Even so, the trade-weighted value of the dollar was below the highs reached in June.

47lbid., pp. 815-16. Although the staff predicted that M2 and M3 growth would slow considerably from the current pace, the growth in the aggregates was expected to remain comfortably within their target ranges. These forecasts for money growth as well as those made subsequently in 1989 , however, were subject to great uncertainty as a result of the uncertainty revolving around the resolution of thrift institution insolvencies and the responses of thrift institutions to recently enacted legislation. These factors were expected to dampen growth in the broader monetary aggregates, particularly that in M3. Thus, any observed weakness in the growth of these aggregates would not be interpreted as evidence of a slowing economy. Ibid., $p$. 816.
}

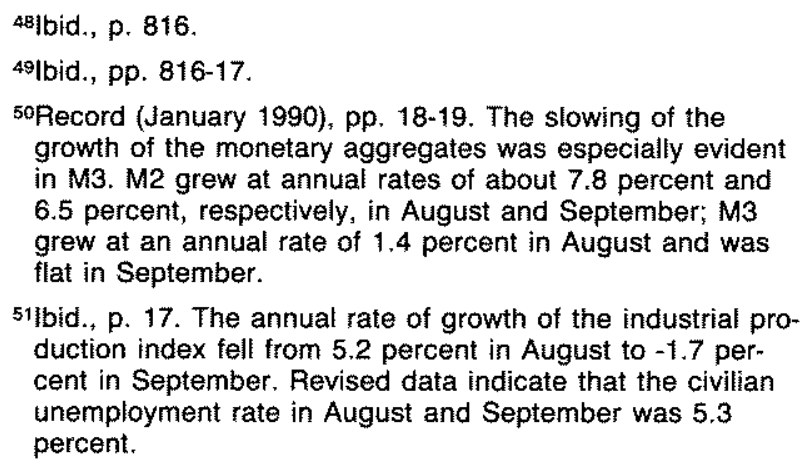

$51 \mathrm{lbid} .$, p. 17. The annual rate of growth of the industrial production index fell from 5.2 percent in August to -1.7 percent in September. Revised data indicate that the civilian unemployment rate in August and September was 5.3 percent. 
ing by more than the value of exports, the U.S. merchandise trade deficit improved further in July..$^{52}$

The price indexes continued to indicate a lower rate of inflation. In August, producer prices fell and the consumer price index was unchanged. ${ }^{53}$ The upward trend in labor costs, however, did not appear to change on a year-toyear basis.

The staff's forecast for economic growth in the remaining part of 1989 and 1990 were essentially unchanged from those made for the previous meeting. Growth in business capital spending was expected to slow from its pace in the first half of the year, however. ${ }^{54}$ Most members believed that, although economic activity would continue to expand in the coming quarters, the pace of the expansion would more likely slow than build momentum. While the members generally expected some weakening in inflationary pressures, only a few thought this weakening might be appreciable. A number of members expressed concern that progress would be constrained considerably if economic activity were to build momentum. Furthermore, the members believed that the recent fall of the value of the dollar in foreign exchange markets would add to future upward pressure on prices. ${ }^{5.5}$

Most members thought that an unchanged policy would be appropriate in the near term. The focus of policy continued to be that of gradually reducing inflation over time and a steady policy course seemed consistent with that objective, at least for the time being. ${ }^{56}$
Growth in the monetary aggregates was expected to moderate from the rapid pace since the middle of the year, given an unchanged policy. Most members believed, however, that future developments would more likely require ease than restraint in the intermeeting period. Nevertheless, the recent depreciation of the foreign value of the dollar warranted caution in undertaking any easing adjustments. ${ }^{57}$

The directive issued at the end of this meeting was written with the understanding that a downward technical adjustment to the borrow. ings objective might be appropriate, if, as expected, seasonal borrowings were to drop in the intermeeting period. The reserve conditions contemplated by the members were thought to be consistent with $\mathrm{M} 2$ and $\mathrm{M} 3$ growing at annual rates of $6^{1 / 2}$ percent and $4 \frac{1}{2}$ percent, respectively, between September and December. The monitoring range for the federal funds rate was unchanged at 7 to 11 percent. ${ }^{5 s}$

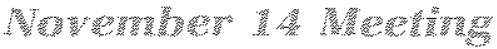

Reserve conditions were eased in mid-October. For a short period after the sharp drop in stock prices on October 13, an accommodative provision of reserves was undertaken while financial markets remained highly sensitive and volatile. Around the same time, in keeping with the previous meeting's directive, a decision was made to implement some easing on a more permanent basis. Incoming data, indicating an increased risk of a weakening in the business expansion, also prompted additional easing early in November. Furthermore, in light of a perceived decline in adjustment plus seasonal bor-

\footnotetext{
521bid., pp. 17-18.

53bid., p. 18. The decline in producer prices, however, was driven largely by a continued decline in energy prices. In August, the seasonally adjusted producer price index for finished goods fell at an annual rate of about 3.1 percent, but, excluding energy and food, this index rose at an annual rate of 6.1 percent. The seasonally adjusted consumer price index excluding energy and food, however, rose only 1.9 percent in August. In their discussion about the outlook for inflation, the members commented that the recent declines in food and energy prices that had dampened price inflation might be temporary. bid., p. 20.

s4lbid., p. 19.

55lbid., pp. 19-20. The trade-weighted value of the dollar relative to the other $\mathrm{G}-10$ currencies fell 2.7 percent over the intermeeting period. A fall in the value of the dollar, holding all eise constant, increases the attractiveness of U.S.-produced goods to foreign importers and U.S. individuals. The resulting shift in demand can create domestic price pressures. A fall in the value of the dollar
}

can also increase the costs of production for those U.S. firms relying heavily on imported intermediate goods, thereby creating additional price pressures. See Hafer (1989) for a detailed discussion of the link between inflation and a dollar depreciation.

${ }^{56}$ bid., p. 20. There was also a concern that, given the recent G-7 meeting, an easing of policy would be mistakenly interpreted as an action to lower the value of the dollar. The Committee believed that monetary policy should not be used as an instrument for achieving a given objective for the dollar in foreign exchange markets if that objective were not compatible with domestic policy objectives. In the view of some members, if recent intervention by $\mathrm{G}-7$ and other nations were to result in a lower value of the dollar, the inflationary consequences would hamper the Committee's ability to achieve its long-run goal of price stability. Ibid., pp. 20-21.

57|bid., p. 21.

58lbid., pp. 21-22. 
rowings, several technical adjustments in the borrowing assumption were made during the intermeeting period. From early October to this meeting, actual borrowings fell from about $\$ 635$ million to about $\$ 200$ million. With most market interest rates falling, the federal funds rate declined from about 9 percent to $81 / 2$ percent in the intermeeting period and growth in the monetary aggregates gained strength in October. ${ }^{59}$

The data reviewed at this meeting indicated that the economic expansion had continued at a moderate pace. Nonfarm employment gains were considerable in October and the civilian unemployment rate did not budge at 5.3 percent. The data also suggested, however, that the strength of expansion was not evenly distributed throughout the economy. For example, most employment gains occurred in the service sector, while manufacturing employment declined. In addition, industrial production dropped appreciably in October, though much of the decline was attributed to several incidents that tended to disrupt production temporarily (the Boeing strike, the earthquake and the hurricane). ${ }^{60}$ The data also showed that retail sales had falten and the growth of business capital spending had weakened. Furthermore, with the value of imports rising and the value of exports falling in August, the U.S. merchandise trade deficit had risen to its highest level thus far in $1989 .{ }^{61}$

The recent behavior of price indexes were consistent with a slight reduction in inflationary pressures. The percentage rise in producer prices fell in October and, excluding energy and food, had hardly changed. ${ }^{62}$ But the data did not suggest any slowing in the growth of labor costs.

In light of the temporary disruptions to production, the staff's forecast pointed to a further slowing in growth in the fourth quarter and a rebound in the first quarter of 1990. On net, the staff predicted that economic growth would continue at a sluggish pace in the coming quarters. Although continuing growth in consumer demand was expected to contribute to economic activity in the near term, consumer demand was expected to weaken subsequently. Further, the forecast indicated that the sluggish pace in the growth of business capital spending would continue and that net exports would not make a significant contribution to the economic expansion. The staff's forecast did not suggest, however, any substantial improvement in the under. lying trend in inflation, ${ }^{63}$

Most members agreed that the data pointed, on balance, to a sustained economic expansion, although growth had weakened recently. But there was no strong consensus among the members about the future outlook. While some members expected that the risks of a stronger-thandesirable expansion and a weaker expansion were evenly balanced, others expected a greater likelihood of either a stronger or considerably weaker economic expansion activity, and still others believed that the chances of an economic expansion close to the economy's potential in the future were not remote. ${ }^{64}$ Similarly, some members believed that progress on improving the underlying inflation trend might be achieved given the recent behavior of the price level indexes and other factors, though others saw that such progress, if any, would be small over the next several quarters. ${ }^{63}$

Although the economic expansion appeared to be slowing, most members advocated a steady policy with no immediate change in the degree of pressure on reserve positions. Such a policy was considered to be consistent with the Committee's goals of promoting a sustained economic expansion while making progress toward reducing inflation in the long run. Moreover, members believed that the recent and expected growth in the monetary aggregates did not warrant any
${ }^{59}$ Report (February 1990), p. 56. The annual rates of growth of $M 2$ and $M 3$ rose to 7.1 and 1.4 percent, respectively, in October. This acceleration was not as pronounced as that in $M 1$ whose annual growth rate rose from 3.9 percent in September to 8.3 percent in October.

60lbid., p. 55. The industrial production index fell at an annual rate of about 4.1 percent in October.

61 Ibid., pp. 55-56.

62lbid., p. 56. Revised data indicate that the seasonally adjusted producer price index for finished goods rose at an annual rate of 6.5 percent in October. Excluding food and energy components, it rose at a 2.0 percent annual rate.

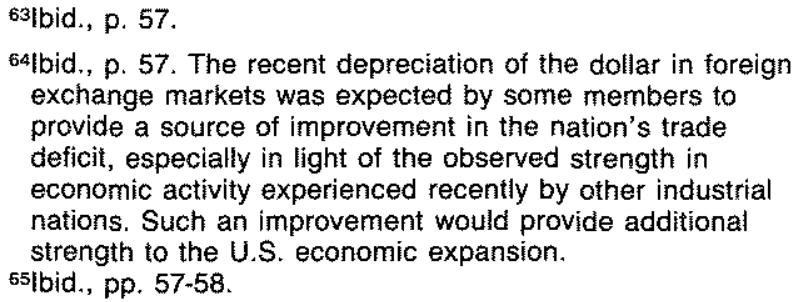


adjustment in policy. Hence, as table 3 shows, the directive issued at the close of this meeting did not call for any change in policy. ${ }^{66}$

Most members, however, believed that the possibility of weakening in the economic expansion exceeded the possibility of excessive growth and, accordingly, that future economic developments would more likely warrant subsequent easing actions than tightening actions in the intermeeting period. Those members who believed that the likelihood of excessive growth was evenly balanced against the likelihood of weakening in the expansion indicated that they could accept a directive containing a bias toward ease in the intermeeting period. But some emphasized the need for approaching possible easing adjustments with caution so as not to detract from any progress that could be made in eventually approaching the Committee's goal of reasonable price stability. ${ }^{67}$

The members expected $M 2$ and $M 3$ to grow at annual fates of $7 \frac{1}{2}$ and $4 \frac{1}{2}$ percent, respectively, between September and December. The monitoring range for the federal funds rate was maintained at 7 to 11 percent. ${ }^{68}$

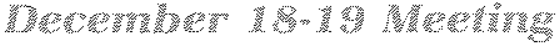

During the intermeeting period, policy aimed to maintain a steady (or unchanged) degree of reserve restraint. Technical adjustments in the borrowings assumption were made twice in the period in light of ongoing declines in seasonal borrowing. During the first two weeks of December, adjustment plus seasonal borrowings averaged about $\$ 130$ million, down from the average of about $\$ 400$ million during the two previous weeks. Meanwhile, the federal funds rate remained at about $81 / 2$ percent and other market interest rates changed little during most of this period. Preliminary data indicated that the growth in the broader monetary aggregates picked up during November and remained robust in the first part of December. ${ }^{69}$
The information available for review at this meeting suggested that the economic expansion in the fourth quarter had slowed from its pace earlier in the year. Although total nonfarm payroll employment made considerable gains in November, these gains were concentrated in the service, trade and financial sectors, with continuing losses in manufacturing. The November civilian unemployment rate, 5.4 percent, was at its highest level since January. Industrial production in November rebounded from its previous decline driven by earlier strike activity among other factors. ${ }^{70}$ Upon adjusting for these factors, industrial production appeared to have fallen, on average, in recent months. In addition, although nominal retail sales rebounded in November, sales had hardly changed from their average in the third quarter, and data indicated a weakening in business capital spending. With imports up sharply and exports virtually unchanged, the nominal U.S. merchandise trade deficit rose considerably in October after having fallen slightly in September ${ }^{71}$

Estimated movements in price indexes continued to suggest a slight weakening in inflationary pressures. For example, the producer price index, based on preliminary data, fell in November. This decline, however, was partly attributable to sharp reductions in energy prices ${ }^{72}$ Although average hourly earnings had fallen in November, the underlying trend in labor cost growth was not expected to change given the results of the recent collective bargaining activities. ${ }^{73}$

The staff's forecast had not changed substantially from the previous meeting. It pointed to a slowing in the economic expansion in the fourth quarter with a rebound in the first quarter of 1990. The magnitude of the rebound was expected to be limited by anticipated declines in motor vehicle production. Economic growth for the rest of 1990 was expected to be driven primarily by moderate growth in consumer spending. Net exports were expected to make a small

\footnotetext{
71lbid., p. 2-3. Total industry capacity utilization having not changed in November from October at 83.1 percent was 1 percentage point below its level a year earlier.

7albid., pp. 3-4. Revised data indicate that the seasonally adjusted producer price index actually rose at an annual rate of 1.1 percent in November. Excluding food and energy, this index rose at an annual rate of 3.0 percent.

rolbid., p. 4 .
}

\footnotetext{
7olbid., p. $t$. The annual growth rate of the industrial production index rose to 3.4 percent in November. It should be noted that the November civilian unemployment rate has been revised to 5.3 percent.
} 
contribution to the economic expansion in 1990. Further, while the staff anticipated that pressures on labor and other resources for production would lessen slightly, no large changes in the underlying trend of inflation were expected. ${ }^{74}$

The members generally agreed that there was considerable evidence that the economy's growth had weakened and would likely remain at a sluggish pace in the near term. Although a number of members thought that some strengthening in the economic expansion in 1990 was a reasonable expectation, most believed that the chances of a weakening were "sufficiently high to justify an immediate move to slightly easier reserve conditions." 75 Those advocating this policy change believed that such a move would not jeopardize the System's credibility of adhering to its long-run goal of price stability, as price pressures and business conditions appeared to have weakened.

Others less optimistic about the potental progress toward reducing inflation favored an unchanged policy. Skepticism about this progress was partly driven by the recent decline of the dollar and the possibility that, if economic activi. ty were to rebound in the next year, inflationary pressures could gain considerable strength. ${ }^{76}$ Those advocating an unchanged policy emphasized that maintaining current reserve conditions would be sufficient to ensure a continuation of the expansion with an easing of pressure on productive resources, and that "further easing might overcompensate for current weakness in the economy at the cost of delaying progress toward price stability." these members, recognizing the risks of an additional weakening in the economy, could accept a policy that sought an immediate but slight easing of the degree of pressure on re. serve positions. In their view, given such a poli$c y$, it was highly unlikely that further easing would be warranted during the intermeeting period. 78

As indicated in table 3 , at the close of this meeting, the Committee issued a directive call. ing for a slight easing of reserve conditions.
This directive did not reflect a presumption about the direction of possible adjustments in the intermeeting period. The Committee expected that the annual rates of growth of M2 and M3 would be $8 \% / 2$ percent and $51 / 2$ percent, respectively, from November 1989 to March 1990. In addition, given the easing of reserve conditions in recent months and the further easing stipulated in this directive, the Committee lowered the monitoring range for the federal funds rate 1 percentage point to 6 to 10 percent. ${ }^{79}$

\section{Gring}

During 1989, the economic data available for review at FOMC meetings prompted Committee members to shift their primary concern from the risks of inflation to the risks of a slowdown in economic activity. At the beginning of the year, the threat of a worsening in the underlying inflationary trend drove the formulation of policy. As the evidence of a weakening economic expansion accumulated and the outlook for inflation appeared to become less threatening, the Committee became more sensitive to the risks of a future slowdown in economic activity. Because the Committee understood that its interpretation of the data was unavoidably subject to great uncertainty, however, it took what it perceived to be a conservative approach to reacting to this information in an effort to balance these risks. This approach was also motivated by the Committee's ultimate goal of eventually achieving reasonable price stability and its desire to maintain its own credibility as an inflationfighter.

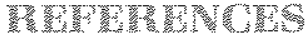

Garfinkel, Michelle A. "The FOMC in 1988: Uncertainty's Etfects on Monetary Policy," this Review (March/April 1989), pp. $16-33$.

Gilbert, R. Alton. "Operating Procedures for Conducting Monetary Policy," this Review (February 1985), pp. 13-21.

Hafer, R.W. "Does Dollar Depreciation Cause Inflation?" this Review (July/August 1989), pp. 16-28.

Hafer, R.W., and Joseph H. Haslag. "The FOMC in 1987: The Effects of a Falling Dollar and the Stock Market Collapse:" this Review (March/April 1988), pp. 3-16.

Thornton, Daniel L. "The Borrowed-Reserves Operating Procedure: Theory and Evidence," this Review (Januaryl February 1988), pp. 30-54. 74lbid., p. 5-6.

75lbid., p. 10.

7albid., pp. 9-10. Over the intermeeting period, the tradeweighted value of the dollar pelative to the other $\mathrm{G}-10 \mathrm{cur}-$ rencies fell about 2.8 percent.

\author{
77bid., p. 10. \\ 7elbid., pp. 1t-12. \\ 79lbid., pp. 13-15.
}

